\title{
The Dilemma Between the Heterodox-the Orthodox Economics and Its Ideology
}

\author{
Ilkben Akansel \\ Artvin Coruh University Hopa Economics and Administrative Sciences Faculty, Hopa/Artvin, Turkey
}

\begin{abstract}
Economic movements have close relation with historical transformations. Historical and social transformations have seriously determined economic views, so, economic movements have been the indicators of economic wars of social classes. But no concept can describe sharp contrast in economics better than the two opponent concepts in economics: "orthodox" and "heterodox" economics. In this article, the reason why neo-classic economics, also called as orthodox economics, has a serious place in economic literature while the opponent's economic movements, named heterodox economics, do not defend only one "truth" and are not as important as orthodox economics will be examined. While doing this examination, Louis Althusser's “ideology" and Antonio Gramsci's "hegemony" will help us as these two concepts are quite instructive in understanding the irreplaceable significance of orthodox economics. As a result, by discussing alternative point of views about economics, positive emphasis of multivocality in economics literature will be revealed. On the other hand, every heterodox economics cannot criticize orthodox economics in the same way. In this study, institutional economics, which is accepted to be part of heterodox economics, will be discussed thoroughly. Institutional economics had a serious attitude against orthodox economics. In this study, generally the points in orthodox economics that institutional economics opposes will be emphasized, and although both economics approaches' ideological attitude will be attempted to be discussed generally, it will become easy to discuss the reason why heterodox economics developed an opposing ideology against the ideology of orthodox economics.
\end{abstract}

Keywords: orthodox economics, neo-classical economics, heterodox economics, institutional economics, ideology, hegemony

\section{Introduction}

History of economic thought is very important as it shows the economic evolution of humanity. Besides, economic transformations in the last century witnessed the sharpest divisions. These divisions especially based on two basic points. A very general division can be made as neo-classical economics, which is the continuation of classical economics and other economics thoughts that cannot be analyzed as a part of classical economics.

It is possible to say that economics can be basically divided into two parts in terms of economics structure: orthodox economics and heterodox economics. Generally, orthodox economics is associated with neo-classical economics; but heterodox economics include almost all the economic thoughts except neo-classical economics.

Ilkben Akansel, Ph.D., Assistant Professor, Business and Management Department, Artvin Coruh University Hopa Economics and Administrative Faculty.

Correspondence concerning this article should be addressed to Ilkben Akansel, Artvin Coruh Universitesi Hopa Iktisadi ve Idari Bilimler Fakultesi, 08600 Hopa/Artvin, Turkey. E-mail: iakansel@yahoo.com; iakansel@artvin.edu.tr. 
But, even when changes between classical economic thoughts and between thoughts in neo-classical views are taken into consideration, exact categorizations about any economic view can change.

Shortly, no one can claim that an economic movement that is a part of heterodox economics will not become a part of orthodox economics in the future. So, it should be known that orthodox economics implies a view that has defined and strict rules and that do not (cannot) go out of these boundaries. In this context, orthodox and heterodox economics can be defined as below:

Orthodox economics: It means giving neo-classical economics apprehension, as it has a hegemonic way which dominates whole economics education, institutions and politics and all other thoughts. Neo-classical economics has a widespread superiority. Since 1970's Keynesian economics has not produced any alternatives to solve the problems of economics in praxis and as a result of this, the theory has been argued. Neo-classical theory has gained superiority. (Emiroğlu, 2006, pp. 661-662)

Heterodox economics: Economists who claim that orthodox economics' political approach is disadvantageous and such political opinions have come together under an opinion called "heterodox economics". We can call the heterodox economics like as such: Austrian Economics, Behaviorist Economics, Black Politics Economics, Ecological Economics, Evolutionist Economics, Feminist Economics, Historian Economics, Georgics Economics, Institutional Economics, Marxist Economics, Post-Keynesian Economics, Post-modern Economics, Post-colonial Economics, Rhetoric Economics, Social Economics, and Sraffa Economics. (Emiroğlu, 2006, p. 346)

When we put up its religious connotations, Orthodox means "correct" (orthos) and "belief, teaching" (doxa), namely, correct belief in Greek. It is used for applications that are about generally accepted views and traditions in economics; economic policies that are made of generally accepted applications are named orthodox economic policies. Heterodox is made of Latin words of "different" (heteros) and "belief, teaching" (doxa); and the word is used for naming applications except traditional views and approaches. (Eğilmez, 2013, p. 1)

In this article, ideological logic of two opposing economy concepts, whose meaning are shortly explained above, will be discussed; because there are two basic reasons why a view is generally accepted. The first of these is that a generally accepted view attempts to ensure that its ideology dominates life completely. The second is that it takes some precautions in order to prevent any other ideology's dominance. In economy, the first resource of orthodox economics' dominance is its union with the desire of being a science which is attempted to be limited with indisputable shapes specially formed at the end of the 19th century (Çakır, 2001): "[...] orthodox economics does not regard any criticisms except the ones made within [...] the only way to make criticisms from within and to reveal its deficiencies is to speak the same language with economists" (pp. 96-97).

So, it can be said that the first ideological aspect of orthodox economics is that it does not accept criticisms; of course this criticism is the ones made outside of orthodox economics. The ideological reason of this is that ideology does not represent reality and the relation between them is symbolic. Reflection of precision in physics of economics is that it developed a belief as "economics can explain every economical phenomenon through mathematics". This limited the field of economics and restricted labor-value concept theory and excluded distribution problem (Çakır, 2001, pp. 99-100). The attitude of orthodox economic that ignores the theory of distribution caused ignoring the problems of labor class which is a big part of social classes and this situation created a consuming based structure.

In other words, economics that is defined as orthodox economics is named as mainstream in economics literature which means that main-stream dominates both processing of state economies and every kind of institutionalization in the system of that economy. 
Mainstream economics here serves to denote the powerful common disciplinary element that has been criticized variously in recent years for its methods and conceptualization of "economic" phenomena. The critiques have come from methodologists and from diverse heterodox theoretical approaches such as feminist, Marxist, post-Keynesian, ecological, Austrian and so on. (Kaul, 2002, p. 709)

The most important criticism made on any view named mainstream is that it does not accept any criticism in terms of its method and information-theory, and it does not regard different voices. In the most general terms, a mainstream view that does not accept any other view can be explained with the concepts of "hegemony" and "ideology". But before analyzing concepts' contents and why do they explain orthodox economics that are accepted as mainstream, we should analyze the contents of heterodox and orthodox economics in a more detailed way.

In this study, in order to observe how heterodox economics ideologically differs from orthodox economics, "institutional economics", which is included in heterodox economics, will be shortly emphasized.

So, in this study, firstly orthodox and heterodox economics' contents will be discussed, reasons of opposing assumptions and general basic points of these opponents will be analyzed; secondly both economics movements' relations with the concepts of "hegemony" and "ideology" will be discussed. The goal of this study is to touch on differences of different economic views in order to show that any economic view can easily become mainstream, and the most important of all, to discuss transitivity of the benefit of economics between the dilemmas of market-society.

\section{The Dilemma of Orthodox-Heterodox Economics}

If one reads the heterodox literature in economics these days, one gets the impression that modern mainstream economics is much like the economics of 50 years ago; it is called "neoclassical economics" and is criticized in almost the same way that earlier heterodox economists criticized the mainstream economics of the 1950s or 1960s. (Colander, Holt, \& Rosser, 2004, p. 485)

It can be said that orthodox-heterodox economics' conflicts dates back to old times; it can even be said that neo-classical economics' criticism started within itself.

It has recently been argued that mainstream economics is in a process of transformation driven by the emergence of a collection of new research programs over the last two decades all of which make important departures from standard neoclassical economics. (Colander, 2000; Colander et al., 2004; Davis, 2006)

These new research programs - including classical game theory, evolutionary game theory, behavioral game theory, evolutionary economics, behavioral economics, experimental economics, neuro-economics and agent-based complexity economics - currently exhibit considerable heterogeneity, reflecting their separate origins primarily in different sciences outside economics and their pursuit by relatively distinct communities of researchers within economics. This development might consequently be taken as evidence that economics is becoming more pluralistic, perhaps under the impact of a "reverse imperialism". (Frey \& Benz, 2004)

But areas of overlap and shared concerns between these new approaches are becoming increasingly evident, creating the possibility of a new general research program for economics that would abandon much of neoclassicism. Thus, the proliferation of new approaches in economics may reflect a transitional state of affairs, which may give way to new orthodoxy and a new mainstream in the future rather than a more pluralistic economics. (Davis, 2008, pp. 349-350)

As we will see in the following paragraphs, birth of new movements in economics agrees with the pluralism principle as each economics approach formed as a result of each criticism of orthodox economics, brought new influences and ensured pluralism in views and approaches. 
For example, it can be said that institutional economics, which is accepted to be a part of heterodox economics, reflects pluralism. One of the most important reasons of these is that it has an evolutionary structure based on Darwinist views, which is also emphasized by Veblen. So, orthodox economics are affected from Newton, who recommends that social scientists can follow their ways and who discovers "the divine order in the universe" (Çakır, 2001, p. 98), and sets off by making a connection between physics-economics; after that defends the claim that "market" will solve every problem without the need of any intervention and differs from heterodox economics as it is not evolutionary. This situation brings this problem with it: Every ideology surely defends that its idea is correct. But the ideologies which can see the mistakes within and let some other ideas enter its discussion can foresee the future and continue. This is why, although the existence of an order that is "divine in the universe" is reflected in the science of economics, nature of human beings that is in a continuous motion is ignored by neo-classical economics. While this human being continues production and consuming by developing caused neo-classical economics become distanced from evolution. This is the side of neo-classical economics that is to be criticized as it is a kind of ideological blindness.

"For instance, in terms of fundamental economics (mainstream economics), companies that are the most basic decision-making unit, are conceptualized as 'black boxes' that transforms production input to products" (Mas-Collel, Whinston, \& Green, 1995, p. 127).

"Fundamental economists (mainstream economists), ... accept that a complete definition of company should include information such as the organization of production, who owns the company; but they limit their analysis with the question of what does a company do" (Binger \& Hoffman, 1988, pp. 230-231).

“... in neo-classical approach, production function that defines product as a function of input... is determined by 'rules of physics"' (Hodgson, 1988, p. 14).

"This approach ignores the fact that production is an institutional activity that includes relations between people and between people and nature, and accepts production as an isolated activity, not being affected from social relations and organizations" (Pirgan Matur, 2007, pp. 283-284).

Besides, both opposing and newly produced mentalities reflect an "institutional" structure ideologically. For instance, if "neo-classical economics" is accepted to be an orthodox structure generally, even if it is thought to be a reinterpretation of "classical economics" in the background, it should be known that it also reflects an opposition to classical economics. The thought of liberalization of commerce defended by classical economists may not reflect the same thought defended by neo-classical economists. Namely, the solution suggestions of an institutional structure depend on its content, requirements, and oppositions.

"Another point that differs is that while—-for instance - physics is a source for inspiration as a method, it can become an ideal for 19th century economists in their analysis" (Çakır, 2001, p. 100).

On the other hand, it should not be forgotten that each economic view is formed either within a previous economic movement or against an economic movement. Being formed within an economic movement is a kind of opposition to make up for the points that are thought to be deficient in that economic movement. This opposition includes two new situations. Firstly, if the opposed view is accepted to be "orthodox", a new heterodox view rises; and secondly, for newly formed a view, there exists the danger to be transformed into an "orthodox" view as it can become introverted.

If it is remembered that ideology is a class struggle (Kazanc1, 2006, p. 10), which can be seen as the connection between physics and economics which is established by the classical economists and the construction of including too much mathematics in economics by neo-classicists is different from each other. In 
neo-classics, "idealist" commitment brought mathematization "too much" with it. Shortly, ideology brought with institutionalization that it in the background of both economic systems will be different. While in classics, an ideology that can be reflected on the lower classes in society is dominant, in neo-classics, mathematical economics equality on paper may not be reflected directly on the lower classes. While firstly classical economics and then neoclassical economics could be accepted as "heterodox" when they first appeared, they turned out to be "orthodox" structures in time.

"In other words, heterodox economics, firstly, is a rejection of a very specific form of methodological reductionism. It is a rejection of the view that formalistic methods are everywhere and always appropriate" (Lawson, 2006, p. 492).

The problem that heterodox economics approaches points in orthodox economics is the problem of methodological reductionism which is claimed to be valid everywhere and at all times. The methodological reductionism problem has a serious problem within which can be defined as "standardization". For instance, when a state's economic polices are taken into consideration, orthodox economics suggest the formula should not be stepped out of specific tools that are applied by economic policy. The economic structures of states vary according to population, social, psychological, urban factors. So, policies applied in X state may not give similar positive results in $\mathrm{Y}$ state. Additionally, $\mathrm{X}$ state that applies alternative policies instead of an economic policy that will be applied according to the formulas suggested by orthodox economics, can have more positive results. But the problem of applying only rigid policies that are required to be applied brings the problem of standardization which results from methodological reductionism problems.

Although neo-classical economics, which is also named orthodox economics, is accepted to be a view that formed within classical economics and carries it one step further, in fact, it is impossible to frame the concept of "orthodox economics" with definite lines.

Defining neoclassical economics is not easy, not least because what one may call neoclassical economics has changed over the years. A broad definition would apply to the original neoclassical economics, founded in the 1870 s, as well as to later work. Another difficulty is that even at one given moment of time the term is not necessarily used in the same sense by everybody. What is called here neoclassical economics is characterized by the combination of the following features: (1) the emphasis on rationality and the use of utility maximization as the criterion of rationality; (2) the emphasis on equilibrium or equilibria; and (3) the neglect of strong kinds of uncertainty and particularly of fundamental uncertainty. (Dequech, 2008, p. 280)

Three features that determine the shape of neo-classical economics are originally the reflections of mathematization. In other words, they are built on a structure that denies production and distribution by focusing on variables that can become quantitative. The reason of its reflection ideologically is that the aim is to ensure that society adopts the economic situation that is wanted instead of seeing the real, existing economic situation. It is possible to represent balance and benefit maximization through mathematics. On the other hand, this situation can cause ignoring problems of income and distribution among classes.

As claimed by Japanese economist Morishima, mathematics is not an objective ideology. Even the use of only mathematics can be an ideological attitude. In the era of serious financial upside-down and class struggles, the use of mathematics, ending labor-value theory and using cardinal benefit-value theory that gives numerical values to everything is completely ideological. (Çakır, 2001, p. 102)

The basic point that is opposed in orthodox economics is that this view completely focuses on market and ignores individual, society, and their benefits. So, we know that the first opposition point to orthodox 
economics is holy triple alliance. The first dimension of criticisms starts from the point of if individuals act completely rationally, if they behave personally and if balance is ensured completely and properly through behaviors. Surely, these oppositions did not come from nowhere; they are formed as a result of a specific amount of time and negativities of the general economic situation.

The story of the evolution of the term neoclassical is a story of metamorphosis. Let me briefly recount its history. The root term, Classical was coined by Karl Marx (1847) as a description of David Ricardo's formal economics; Marx contrasted Classical with vulgar or romantic economics, by which he meant "economics close to the people." Various writers used the "Classical" terminology and, as they did, the term eventually became a general classifier for the economics of the period running somewhere between 1776 and 1870 . Thus we could talk about the evolution of thinking from the mercantilist to the Classical period. Historians of thought have raised numerous issues about the use of the term Classical. One issue is, when did the Classical period begin? Schumpeter, following Marx, starts the Classical era with Ricardo. He places Adam Smith with the mercantilist pamphleteers, taking the Classical period as 1790 to 1879 . Most histories of thought include Smith as a Classical economist. Most writers put the end of the Classical period a bit earlier - in 1870 - and start the neoclassical period with Carl Menger, but such beginning and ending issues, unless they involve a writer of the stature of Smith, are of minor importance. (Colander, 2000, pp. 130-131)

It is understood from here that, although it is not accepted the difference of orthodox-heterodox, views that support one another's views or completely contrary to each other can bring us as far as Karl Marx. But the "classical economics" generally associated with Adam Smith's definition gave birth to neo-classical economics, which had been indisputable until 20-30 years ago, by getting closer to the concept of market economics. Surely this transformation can be separated from social changes, so the social significance of orthodox-heterodox should not be ignored.

Similar to other mainstream views, orthodox economics is associated with hegemony on institutional structures; the meaning of institutional structure includes a wide range of issues such as educational institutions and teaching staff. Another issue about orthodox issue that is opposed is these institutional structures which are difficult to enter in and out. No matter how fierce the social transformations are, they may not find their economical responses appropriately. Neo-classical economics that have completely penetrated into the functioning of economics, education etc. is also followed by significant economists of today; this situation can only be explained with the concept of "hegemony".

Antonio Gramsci is one of the leading scientists of Marxist thought. [...] He indicates that Marx did not emphasize the need of strategic politics in class struggle; because maintaining the capitalist relationships government is huge activity. The power of the dominant class does not only come from force; it also serves through gaining power in political and cultural area. [...] Government surrounds all non-government areas. The government is a tool which helps to achieve the power of dominant group. (Portelli, 1982)

The key concept about culture and ideology of Gramcsi's is "hegemony". This concept is connected with culture, power, and ideology. The main curiosity of Gramsci's is how an elite group can govern the rest of the society (numerical majority) and how the major group can accept to be governed in that way. How an elite minority can govern the majority without using force? Gramsci finds this answer in "hegemony" concept. [...] Because, this minority has the government and its organs and mass communication tools which are the main institutions of the country. Thanks to these tools, the rest of the society is controlled by the minority. Gramsci mainly understood from the concept of hegemony which means controlling other parts of a society ideologically and culturally. This is why; administrator class of a society can affect non-government society. Dominant group has the basic tendency to affect entire belief system of a society, moral codes, family, schools, and unions through church. Hegemony can be explained as a society's being governed, controlled by the thoughts of a dominant group. Thoughts of the dominant group are perceived by entire groups of society and they are normalized. The dominant group in order to protect and sustain and permanent the prosperity and occupied position in the 
society will attribute its own philosophy, science, cultural and moral values to the society. (Gramsci, 1997)

They hide the classified and make them common character of these values and thoughts judgment of the society. They make all other judgments and all other philosophies which can be removed and make the dominant ideology unrivaled. [...] According to Gramsci, the dominant group takes its power either by using strength or providing people's consent, or using both of it. Institutions like military, policeman, judge, and prisons are necessary in order to govern through force. So, people are subjected by using physical power. However, according to Gramsci, no dominant structure can be governed by only using force. According to Gramsci, convenience is the acceptance of a dominant class's worldview and thinking by the members of the society. Institutions such as schools, churches (religion), and media are produced and re-produced by human thought. Through these kinds of institutions, dominant group spreads its own way of thinking and view. If people face any social problem they will perceive events in the way that they were taught by dominant class. They think that this point of view is natural and they are common sense. Common sense describes the events as how everyone knows it. [...] In this way, after describing social structures and social relations, people do not think that it is necessary to change them. Thus, it seems natural that some people are rich and some are poor. Because, there is no equality in nature. [...] But, Gramsci emphasizes the struggle; in his opinion, "common sense" is not a stable thing, it is in a constant and change. Convenience must always be gained and re-produced. Because, people's social materials always remind dominants about their disadvantages. And this situation causes a threat to dominant group. (Yaylagül, 2006, pp. 96-100)

So, orthodox economics that has a hegemonic significance of the function, application, education of the economy, stating views etc. achieves and continue dominance through the tools of the system from which it comes. For instance, in all over the world, neo-classical economics is significant in education; this situation can also be seen in Turkey. Extent of heterodox economics, as far as is known, is not taught in university classes. Media makes news mostly about the stock market and various markets. So, society is always under the effect of dominant group both ideologically and culturally. This dominant situation also affects economic policies of countries. If it is accepted that dominant group defends orthodox economics, in the applications of national economics, applications of dominant view are preferred. Hegemonic dominance in institutional structures, namely, this power in the organizations that are responsible for the economy in the society and in economy media, reaches each person one by one and it causes them expect solutions from the structure which is in fact the beginning of the same problem. This is the point that is opposed by heterodox economics as it is a "hegemonic power". Orthodox economics' hegemonic part is that voice of the alternative solution suggestions for the problems originating from structural causes are not heard enough. At the same time, it is one of the points opposed by heterodox economics.

At this point, another feature of the concept called "mainstream" occurs. The concept of mainstream is a thought system that generally continues for a long time, has a specific tradition and rules that are accepted, and have become a "school" in time. One of the main reasons why heterodox economics is not generally accepted is that it is not accepted as a "school". Surely, it should not be forgotten that this view is also held generally in neo-classical economics.

The terms "orthodox" and "heterodox" have been used in various ways in economics, but in the discussion above they are treated as sociological terms that define what is generally regarded as conventional or unconventional in the economics. There are two important implications of this interpretation. First, neither "orthodox" nor "heterodox" inherently refers to any particular type of approach in economics; alternatively, any kind of approach in economics can be orthodox or heterodox depending on historical conditions, and indeed in the history of economics most major approaches have been both at one time or another, and not infrequently both at the same time, though in different locations. Second, though there has often been a close correlation between individual economists' professional success and their association with conventional approaches, this has tended to be more (though not exclusively) the case when a dominant approach exists, whereas in periods of pluralism, when what is conventional is unclear or under challenge, many individuals can be quite 
successful professionally though their approaches are still unconventional. For example, today both behavioral and experimental economics are not conventional, though many of their main contributors are very successful professionally [...]. (Davis, 2008, pp. 353-354)

Although there are different opponents, evaluating entire economic views in one group is not a correct approach. For instance in historical process, social events affect one another, namely, the end of one phenomena can be the beginning of another; history of economics is similar to that process, many views in economics in fact try to make up for the deficiency of another. On the other hand, economic views of heterodox economics have brought different solution suggestions to the same problems. In this case, "traditional" and "non-traditional" features are other clues for us in order to determine which view is orthodox, which is heterodox. Namely, while orthodox economics is traditional, heterodox economics is non-traditional. Besides this, while a view is not traditional, views that contribute to it can be traditional.

Although it is not a general definition, it is possible to attribute economic view named "heterodox economics" to Karl Marx. Possibly because of this, it is claimed that heterodox economics has a social side. Although economics historians wanted to classify views and tried to differentiate views from one another with sharp lines, if economists do not want to be a member of such classifications, they can be the member of a group they want. Besides, it is also incorrect not to evaluate completely opponent views in terms of orthodox-heterodox differentiation. Point of view of the nature of orthodox-heterodox economics that cannot be separated from sociologic meaning, about economic process that is affected by social phenomenon should also be discussed:

[...] For example, a core principle in orthodox neoclassical economics is that individual behavior is rational, and a common defense of the principle is that "it could not be otherwise" (thus suppressing reference to other forms of conceptualization). In contrast, a periphery principle in traditional Marxist economics is that individual behavior reflects class location. The Marxist explanation is heterodox in virtue of explicitly lying outside the core of the field, but the concept of class also bears a relation to the boundaries of economics in light of its important role in sociology [...]. (Davis, 2008, p. 355)

The significance of the concept of "class" in terms of sociological dimension is also vital in economics. Because, "class" concept includes an institutional structure, so this institutional structure contains economics. If the economics is accepted to be a big organization-according to us, it should be so-it is impossible to differentiate and isolate small organizations within economics. According to us, the biggest separation point of economics as orthodox and heterodox economics stems from here. The hegemonic attitude of orthodox economics, which is accepted to be "elite" and affects the general process of economy, schools, and professionals hide behind a big ignorance. Namely, not including small organizations that create big organization in time, or including them but ignoring their thoughts is the most deficient part of neo-classical economics.

The hegemonic side of orthodox economics' "elitist" attitude cause formation of an opposing economics named "heterodox" economics. As hegemonic power, the dominant power that can affect both economics literature and economy policies applied by governments can be dominant everywhere. But because of "not introducing new views" into its ideology, it causes some problems between classes. Especially voice of classes that does not get enough share from production and distribution of it cause emergence of other economic ideologies. Namely, economic movements that can be defined under the title of hegemonic economics emerge from spaces caused by hegemony. For instance, if neo-classical economics focus on mathematics too much, as 
hegemonic economic movement sees this as a deficiency that can cause problems, it will try to fulfill this gap with a new ideology.

Another deficiency caused by mathematization can cause ignoring especially struggle among classes; and this situation is assumed to be significant as entrepreneurs represent "industry" as an upper class.

"[...] how and why economic activities are carried out not by isolated individuals, but by groups that entrepreneurs get to cooperate in such larger entities as firms, industries and inter-industry groups..." (Granovetter, 1992, p. 6).

A mathematical method that is used by orthodox economics while explaining economic phenomenon is in fact mathematical presentation of a line of ideas. Although correctness of mathematical representation are proven on paper, it may not help solving a problem in reality. Numerical estimations may not completely and correctly reflect reality. Mainstream economists may get lost in analysis and present a good solution to the problem; moreover they think that creating solutions that cannot be sometimes understood by professionals are prestigious. Of course such solutions earn respect and prestige but for example a mathematical model that does not present solution for economic problems can earn reputation in a limited environment.

Easiness brought by mathematics, either based on personal choices or on company preferences, cannot be ignored; because as mathematical analysis is based on absolute accuracy, it will bring a definite and expressive solution to economical phenomenon on paper.

Saying that modern economics follows a modeling approach does not mean that other periods did not use models. Economists have always used models. But there is a distinction in how the models are used. To see the distinction between modern economists' use of models and earlier economists', it is useful to distinguish between pure theory models and applied policy models. Formal modeling has always been the essence of the pure theory of economics - metaphysics, or science, depending on one's view. For example, Franciois Quesnay, Ricardo, Cournot, and Walras all simplified their views to develop a theoretical model. Modern pure theory has evolved from the general equilibrium theory of Walras to the general equilibrium of Arrow/Debreu, but the modeling approach has not changed. These pure theory models are highly formal and mathematically deep. But such formal models are not the type of models that the large proportion of economists deals with. [...] Previously, economists such as Smith or Marshall kept the theory in the back of their minds and thought about the policy problem as an art. Their models were kept in the background, and reasonableness-critical thought - was emphasized in applying the models. In modern economics that has changed. There is no art of economics in which policy problems are addressed in an informal manner. Modern applied policy models must be specified in a way that can be directly empirically tested, at least in principle. While such models are informal by mathematical standards, they are formal by artistic standards, which is why some observers call modern economics formalist. (Colander, 2000, p. 138)

As seen from above, methods of significant economists had a big influence when they were firstly used, but had become insufficient in time as an economic structure, namely, modern economics developed. Surely, mathematics is one of the strongest instruments that can be used in a scientific study. In fact, it is a useful instrument, but it is intensely criticized as instrument became goal in time.

Another point that should not be ignored is that economists in that era that use mathematical modeling is generally engineering origin. Surely, the reason why these economists gave importance to this mathematical modeling was that after the strong bond with physics and economy, physics started to be a definite science. Besides this, during the renewal after the break after Marshall, a significant break occurs between economics and physics. Differences between economics mathematical models established by neo-classicists and modern economics applications are because of this reason.

No matter which economics approach is used in the scope of heterodox economics, one of the first issues 
that we meet is the irrepressible success of mathematics, in other words, mathematics" "exceeding" suppressing.

An increase of multivocality in economics surely led to the addition of many new views to the literature of economics. Besides new views, there occurred an increase in the number of important economists. But this increase in quantity caused new problems such as the questions of which view can be classified in which way, if classification is necessary, if new schools are formed because of classifications.

Pioneer of institutional economics, Coase explained exceeding suppressing of economics, pioneered by mainstream economics as follows:

Commentators routinely note that modern economics is failing as an explanatory project. [...] According to the 1991 Nobel Laureate Ronald Coase, "Existing economics is a theoretical system which floats in the air and which bears little relation to what happens in the real world" (1999, p. 2). For Coase the discipline is in urgent need of substantial transformation and he suggests that there may currently be support for such a program of reorientation precisely because of the growing recognition of the inadequacies of mainstream economics: [...] universalisation of formalistic methods combined with a failure to question whether such methods are appropriate to the contexts in which they are applied. The mainstream demands that formal modeling methods should be applied, almost always without making any assessment of their suitability for investigating social material. It is simply taken for granted that such techniques are appropriate for, or perhaps more accurately essential to, economics. [...] All methods, including mathematical ones, are appropriately applied in some conditions but not others. These are the ontological presuppositions of those who wield these methods. When considering the prospects for, and likely consequences of, pursuing mathematical modeling, whether in economics or elsewhere, the Cambridge group recommends an evaluation of the relevance of such presuppositions in the context in which their use is being proposed. [...] The sorts of formalistic methods used by economists presuppose that the domain of reality being investigated is "closed" when, in contrast, it seems to be the case that social reality is quintessentially open. A closed system is one within which regularities of the form "whenever event or state of affairs $\mathrm{x}$ then event or state of affairs y" obtain. These regularities can be deterministic or take a probabilistic form. They are the sort of correlations achieved, via human intervention, in well-controlled experiments. By supposing formalistic mathematical methods to be always appropriate mainstream economists assume that something at least approximating experimental conditions hold everywhere in the social realm. The difficulty for the modeling approach is that the social realm is of a nature that such conditions are rarely found to obtain. [...] To produce an event regularity in a well controlled experiment the experimenter, typically, has to identify a stable mechanism and effectively isolate it. [...] The (isolated) mechanism has to be intrinsically stable so that when it is triggered (conditions $\mathrm{x}$ ) predictable effects (outcomes y) always follow. [...] In fact, the results achieved can be applied outside the experimental context precisely because they relate to the underlying mechanism, not to the event regularity corresponding to its empirical identification. (Pratten, 2004, pp. 37-38)

Generally, basic problems of all the economics branches of heterodox economics are that they cannot go out of the stereotyped views of orthodox economics, while mathematics is a necessary and useful instrument of assumptions, it has transformed into a goal and alternative views' acquisitions are ignored. Although some of them were included in the mainstream, the most important name that marked economics literature made serious criticisms about the issue and they stated that they are against excessive prescriptivism.

Namely, one of the basic contradictions is that both orthodox and heterodox economics start to be prescriptive when they were forced to be formalized. Prescriptivism cause not being able to go beyond a specific ideological logic. Social realities are ignored more. A process of turning from a human-centeredness which is required by its sociologic nature, to a market-centered conceptual frame, generally to mainstream ideology occurs.

In general terms, the most general features of "mainstream" ideology are prescriptive, which have a distorted factuality that is assumed to be the truth etc.. 
According to Althusser's theory, practice of society and ideology are intermingled (1) If it is remembered that ideology is not a representation of reality, it is the representation of relation through reality, it can be said that; (2) Ideology does not have a history. Ideology is a war of classes; and (3) "Ideology assumes individuals as subjects and named them as a subject. [...] Ideology turns individuals into subjects through naming. [...] In this way, individuals play the roles which are expected from them within the limits of being subjects. (Kazanc1, 2006, p. 10)

We need to emphasize below mentioned issues in order to show what ideology represents in terms of our topic:

(1) When neo-classic economics' practices are applied in economic life and affect all actors in the economy, the actors of economics think that these practices are normal and they make their life better. But, actually the practices that are applied make some actors richer and some actors poorer;

(2) Human history is a history of war. One of the most important reasons of this war is economics. In human history, human beings are always classified. May be it is impossible to explain this with "classification", but people have always faced some kind of discrimination. So, the conflicts between orthodox economics and heterodox economics are based on the question that which one of them gives much better economical life to people;

(3) On calling economics life as "free market" we are given the all actors freedom in that system. Of course, freedom is desirable for everybody but, one can remember that an actor that has power can design the market however he wants. This may sound good. But, when individuals are transformed by naming method, and if they do not play the roles expected from them, the role of "individual" that is the subject of neo-classical economics will change. For example, the neo-classic economics expect individuals to play their roles as "individuals" and these individuals are expected to make analysis and firms are expected to maximize their profits. If they do not find any solutions because of the crisis, what kind of new solutions can be applied by firms? While the ideological logic of orthodox economics can be explained as above, the ideology of its becoming mathematical is that mathematics becomes a subject and prestige ideology is supported.

According to Katzner (2003), mathematics may have become important because of four main reasons:

This paper suggests that mathematics may have become so important in economics for four reasons: (1) to make use of existing human capital; (2) to attain scientific respectability; (3) to help assure security with respect to claims of truth; and (4) because economics was created primarily by western economists to understand western economic behavior. (p. 561)

In this article, Katzner discusses the issue through Roy Weintraub's book How economics became a mathematical science which he wrote in 2002. Point of view presented by Katzer really enlightens us in terms of the use of mathematics in economics. Although relating mathematics to the science of economy has created negative results, it also positively affected some unknown points.

Making use of human capital may be easy on paper with mathematical computing. But while there are questions of if individuals can have equal amounts of human capital, even when they have equal amounts of human capital, are they employed equally and under equal conditions etc., how can mathematical data on papers be applied in reality? This is a problem.

Economics science is probably the closest to sociologic concepts. Abstraction from social context may cause it to be respected more by science environments, but it causes being estranged from social problems. Giving less significance to its sociological side does not decrease its prestige. Increase of becoming mathematical brings more professionalism within which will make it harder to be understood, even by professionals. 
A respect could be gained by mathematical truths, but it may cause a significant disengagement between theory and praxis. While evaluation of economical behaviors and the wish to direct market behaviors by easily observing them was very valid at the beginning, a solution could not be found especially for the problems in the last five or six years.

So, heterodox economics that contributes to economics literature and has some opposing points to orthodox economics, which have so many problems within, should be analyzed more broadly. But when the first definition we made about heterodox economics is taken into consideration, it is impossible to discuss entire heterodox economics. This is why heterodox economics will be discussed in detail and the focus will especially be an institutional economics that is a part of heterodox economics.

Heterodox economics would therefore be defined by its lesser prestige and influence. [...] Like mainstream economics, its heterodox counterpart may or may not have shared methodological, theoretical, or political features at any particular point in time. When they exist, these shared ideas may also change over time, as some of them may be incorporated into the mainstream, while ideas that have enjoyed prestige and influence for some time may be expelled from the mainstream paradise. (Dequech, 2008, p. 295)

As can be seen, heterodox economics starts criticizing when orthodox economics, which is accepted to be a hegemonic power, have a missing point. This situation is already in hegemony's nature; namely, although dominant ideology controls everywhere, there are definitely some conditions, and this causes birth of opposing hegemonic views that will criticize the dominant ideology. For instance, orthodox economics' mathematician is criticized by heterodox economics. Besides this, ideology sometimes includes some opposing ideologies which can cause - although partially — the result of adding some heterodox views to mainstream ideology.

The most significant feature that heterodox economics opposes and stands against as a hegemonic power is pluralism. One of the heterodox economics approach that pluralism reflected the best is institutional economics, because in economic approach that can be named "real institutional economics", all of the economic phenomena are named to be institutions that are in mutual interaction which caused evolutionary point of view to economics. Apart from all movements that can be included in heterodox economics, institutional economics deal with all of the institutions that create a society. This is why it has a close connection with pluralism.

[...] In the interwar period, institutionalism made strong claims for itself as a school and succeeded in becoming the most visible, if not the dominant, group in American economics. The movement cohered not around a tight theoretical agenda but around a particular view of science and a conviction of the inadequacy of the unregulated market. It cannot be said that institutionalists such as Thorstein Veblen, Wesley C. Mitchell, Wahon H. Hamilton, John R. Commons, J. M. Clark, Rexford Tugwell, and M. A. Copeland all pursued exactly the same research program or utilized the same techniques of investigation. Institutionalism included Mitchell's quantitative methods, Commons' documentary histories and interviewing, Hamilton's case studies of firms and industries, and Clark's applied theorizing. Institutionalism consisted of a number of loosely related research programs, one cluster centering on business cycles and unemployment, with a reform agenda involving some notion of overall planning, and another cluster centering on the legal dimensions of markets, with a reform agenda focusing on labor law and business regulation. [...] As we have said, pluralism is not to be understood as a code word for "institutionalism". It was a genuine pluralism, to be taken in a positive sense. Pluralism meant variety, and that variety was evident in beliefs, in ideology, in methods, and in policy advice. We are used to thinking about the institutionalists as difficult to pin down because of their varied interests and practical approaches. But variety appears to be true in general, for there are no clean lines separating schools; indeed, it is not even clear that one can specify schools. (Morgan \& Rutherford, 1998, pp. 2-4)

So, pluralism will enter into each field of science and enrich it both in terms of method and theory. 
Especially as this science is economics which involves the entire material-moral phenomenon in human nature, its ideology is criticized both in terms of theory and method.

Although the point that heterodox economics opposes in orthodox economics approach is its method, at some points, heterodox approaches coincide with orthodox economics' method. This means that, when all negative criticisms take into consideration, each approach carries traces of orthodox features more or less. When a heterodox view ignores the points it opposes in orthodox economics, and more importantly when it moves away from its sociologic concept, it has a tendency to transform into orthodoxy. Besides this, part of the method of institutional economics that is defined as a part of heterodox economics which separates it from orthodox economics' method that is close to monotype is that different institutional economists could define different methods.

Among institutionalists, the concept of science seems to have been based on a view of natural science methods as empirical and experimental. Mitchell's quantitative approach was quite explicitly modeled on what he thought of as the nearest approach to the methods of the natural scientist that it was possible to achieve in economics. But other institutionalists did not place the same emphasis on quantitative methods as did Mitchell; Tugwell talked of experimental economics, and Copeland talked of the natural science point of view. Although the specific techniques of investigation used by institutionalists varied, in all cases the goal was to investigate actual conditions and to create a theory that was based on realistic assumptions and that could address real world issues and problems. (Morgan \& Rutherford, 1998, p. 6)

Surely, it should not be forgotten that this difference in method is determined by definite differences in institutional economics. What we mean by difference is that institutional economics is divided into two as "Old Institutional Economics" and "New Institutional Economics".

[...] This "New Institutional Economics"-distinguished from the old by its reliance on arguments for the economic efficiency of observed institutions - was closely allied to the "New Economic History", which made similar claims for historical settings. Property rights, enclosures, and all manner of political and legal institutions came to be interpreted as the efficient outcome of rational individuals pursuing their self interest (e.g., North \& Thomas, 1973; Ransom \& Sutch, 1982). And these new interpretations were applied even to spheres far from economists' traditional domain, such as the family, crime, altruism, and animal behavior (e.g., Becker, 1976, 1981). [...] One unifying theme of my current work is that the new economic imperialism attempts to erect an enormous super structure on a narrow and fragile base. A more solid foundation can be constructed on the basis of three classic sociological assumptions: (1) the pursuit of economic goals is normally accompanied by that of such non-economic ones and sociability, approval, status, and power; (2) economic action (like all action) is socially situated, and cannot be explained by individual motives alone; it is embedded in ongoing networks of personal relations rather than carried out by atomized actors (for an earlier programmatic statement see Granovetter (1985)); and (3) economic institutions (like all institutions) do not arise automatically in some form made inevitable by external circumstances, but are "socially constructed" (Berger \& Luckmann, 1966). [...] The more recent generation of economic sociologists, who constitute what I call the "New Economic Sociology", have looked much more at core economic institutions, and are closer to such intellectual forebears as Emile Durkheim and Max Weber-who regarded economic action as a subordinate and special case of social action-than to the accommodations stance of mid-century sociologists. An important part of this focus is a sociological theory of the construction of economic institutions. Such a theory must make Dynamics central, in contrast to most neo-classical economic work on institutions which (like many branches of economics) emphasizes the comparative static of equilibrium states. Without explicit dynamic argument, we have the irony that economics, despite its devotion to methodological individualism, finds itself with no ready way to explain institutions as the outgrowth of individual action, and so falls back to accounts based on gross features of the environment. (Granovetter, 1992, pp. 4-5)

If we take the close connection between economics and sociology into consideration, this situation can be explained through three points: (1) Sociological classifications can determine economic classification, namely, 
economic decisions made by individuals can sometimes be determined according to social status and power in society rather than rational choices. In other words, their expanses may not be determined solely by their "incomes"; (2) A consumer individual may have not shown an economical behavior with personal motivation. His/her social personal relations may affect economic behaviors; and (3) As in all institutional structures, economic institutions are built sociologically. This means that economic structure making society is determined by that society's social, psychological, cultural etc. factors. If sociologic structure creates economic structure, then this assumption accepted by generally all heterodox economics literature as a common view cannot be ignored: Continuing orthodox economics' entirely market-based structure only with the aim of making more profit can lead to serious crises. This is why, instead of focusing on market, applying policies that will ease market actors economically, which is good for both economics and society.

With all these, it is also claimed that institutional economics have a revolutionary feature. This feature can be seen in these points: It wants to be regarded as completely apart from classical economics perspective (phenomena); it gives a new impulse to solving the problems of economics literature out of standard economics policies' oppressive, boring, etc. environment.

One of the reasons of that staying power is that it provides a foundation for institutional thought-a reason for the Association for Evolutionary Economics to exist. It does so by distinguishing institutionalists from standard economists. In this paper I distinguish institutionalists (with a capital I), by which I mean the institutionalists within AFEE who maintain direct ties to old institutionalists, from quasi-and neo-institutionalists (with a small i) who spend far less time emphasizing those ties and whose work is considered part of modern mainstream economics. [...]

- Institutionalism represents a revolutionary way of observing economic phenomena that is not complementary to classical economics.

- Standard economics is too pessimistic. Its overall policy message is that "if something must be done about economic conditions do the least possible and be cautious about that" (Hamilton, 1999, p. vii). Institutionalist economics offers a much more optimistic view of policy.

- Standard economics follows a mechanistic Newtonian point of view, whereas institutionalist economics follows a "process tools" approach, which captures the evolution reality of economic change.

- The difference between institutionalist economics and standard economics can be found in their concepts of change.

- Institutionalist economists are more capable of coming to grips with the major economic issues. (Colander, 2003, pp. 112-113)

Shortly, moving out of the structure of orthodox economics - also called neo-classical economics - which focuses economy only on the market, namely, limits economy generally with financial accounts, can be made by heterodox economics. Heterodox economics, which accumulates new ideas, are more flexible in terms of ideological structure, it is more open to both development and criticism. Hegemonic power that will be created by heterodox economics will be much more focused on orthodox economics. In private, when institutional economics is analyzed, which is accepted to be a part of heterodox, a very new impulse is brought to the economics by taking both old and new theorists' criticisms into consideration. Especially the assumption that economics should have an evolutional structure can be seen as an ideological structure that will make a significant contribution to the ideology of orthodox economics. 


\section{Conclusions}

Economic periods are full of rise and falls such as contractions and expansions. But some periods cause such huge booms that some points that are known to be true in economics have to be revised. The best historical example of this is 1929 great depression. Besides this, 2008 crisis is another example which still has some dimensions that could not be overcome.

Because all of these, it is possible to divide economics generally into two completely opposite poles: orthodox economics and heterodox economics. In the literature, orthodox economics is named "neo-classical" economics while heterodox economics includes all different kinds of schools of thought except neo-classical that are named differently such as institutional, behavioral, Austrian School etc.. Although the names are different from one another, heterodox economics opposes orthodox economics in terms of some specific points. Of course when each school of thought analyzes in detail, although the points that they oppose differ from one another, the points that heterodox economics criticizes basically are: Being market-based, becoming mathematical too much, transformation to an ideological structure, and having the hegemonic power in this context.

In fact market-based side of orthodox economics and its aspect of becoming very mathematical can be explained by the fact that it determines economical ideologies through its hegemonic power. Orthodox economics rules education, economic policies of governments, media, and many other ideological instruments of governments as the dominant power, so it transfers its ideological reason to all of the economic actors of society through these instruments.

The relation that the first established of neo-classical economics wanted to build between physics and economy left a connection to neo-classical economics ideologically: inflexibility in terms of recommendations, ignoring different ideas on different topics. Being stuck in some theoretical frames ideologically with this effect given by hegemonic power can be accepted as the biggest deficit of neo-classical economics.

Especially institutional economics is full of significant oppositions to neo-classical economics. In fact, as a hegemonic power, one of the best ways to be applied by neo-classical economics is to incorporate new recommendations of different economic approaches; in this way, the existing theoretical frame will be enriched and it will be less criticized. For example, the point which neo-classical economics is criticized the most is that it incorporated mathematics too much. While mathematization makes economic phenomenon more explainable, it cannot produce solutions to inequalities among classes. This situation causes mathematization's being used as an ideological device, and it is assumed to be the hegemonic power area that heterodox economics opposes the most.

So, in most of the institutions where economics education is given, either education system cannot go beyond the limits of neo-classical education or it can only embody heterodox economics very little. This situation affects professionals in education institutions too. While using mathematical methods too much while explaining any given concept can ensure prestige, it also causes these professionals not being understood.

Shortly, orthodox economics, which cannot generate new solutions to repetitive and economic problems, has to regard solution suggestions of heterodox economics which embodies pluralism more.

\section{References}

Becker, G. (1976). The economic approach to human behavior. Chicago: University of Chicago Press.

Becker, G. (1981). Treatise on the family. Cambridge, M.A.: Harvard University Press.

Berger, P., \& Luckmann, T. (1966). The social construction of reality. New York: Double-day.

Binger, B. R., \& Hoffman, E. (1988). Microeconomics with calculus. London: Scott Foresman and Co.. 
Çakır, N. (2001). İktisadın Dama Taşları (Checkers economics stone). İstanbul Üniversitesi İktisat Fakültesi Mezunları Cemiyeti İktisat Dergisi (The Journal of Istanbul University Faculty of Economics Alumni) (pp. 96-111).

Coase, R. (1999). Interview with Ronald Coase. Newsletter of the International Society for New Institutional Economics, 2(1), 3-10.

Colander, D. (2000). The death of neoclassical economics. Journal of the History of Economic Thought, 22(2), 127-143.

Colander, D. (2003). Are institutionalists an endangered species? Journal of Economic Issues, 37, 111-122.

Colander, D., Holt, R. P. F., \& Rosser, J. B. Jr. (2004). The changing face of mainstream economics. Review of Political Economy, 16(4), 485-499.

Davis, J. (2006). The turn in economics: Neoclassical dominance to mainstream pluralism? Journal of Institutional Economics, 2(1), 1-20.

Davis, J. B. (2008). The turn in recent economics and return of orthodoxy. Cambridge Journal of Economics, 32, 349-366.

Dequech, D. (2008). Neoclassical, mainstream, orthodox, and heterodox economics. Journal of Post Keynesian Economics, 30(2), 279-302.

Eğilmez, M. (2013). Ortodoks ve heterodoks ekonomi politikaları (The politics of orthodox-heterodox economics). Retrieved from http://www.mahfiegilmez.com/2013/04/ortodoks-ve-heterodoks-ekonomi.html

Emiroğlu, K. (2006). Ekonomi sözlüğü (The dictionary of economics). Ankara: Bilim ve Sanat Yayınları.

Frey, B., \& Benz, M. (2004). From imperialism to inspiration: A survey of economics and psychology. In D. J. Marciano, \& J. Runde (Eds.), The Elgar companion to economics and philosophy. Cheltenham: Elgar.

Gramsci, A. (1971). Selections from the prison notebooks. New York: International Publishers.

Granovetter, M. (1985). Economic action and social structure: The problem of embeddedness. American Journal of Sociology, 91, 481-510.

Granovetter, M. (1992). Economic institutions as social constructions: A framework for analysis. Acta Sociologica, 35(3), 3-11.

Hamilton, D. (1999). Evolutionary economics: A study of change in economic thought. Piscataway, N.J.: Transaction Publishers.

Hodgson, G. M. (1988). Economics and institutions: A manifesto for a modern institutional economics. Cambridge: Polity Press.

Katzner, D. W. (2003). Why mathematics in economics? Journal of Post Keynesian Economics, 25(4), 561- 574.

Kaul, N. (2002). A critical "post” to critical realism. Cambridge Journal of Economics, 26, 709-726.

Kazanc1, M. (2006). Althusser: İdeoloji ve ideoloji ile ilgili son söz (Althusser: Ideology and the last word about the ideology). İstanbul Üniversitesi İletişim Fakültesi Dergisi, 24, 1-20.

Keynes, J. N. (1897). The scope and method of political economy. New York: Macmillan.

Lawson, T. (2006). The nature of heterodox economics. Cambridge Journal of Economics, 30, 483-505.

Mas-Collel, A., Whinston, M. D., \& Green, J. R. (1995). Microeconomics theory. New York: Oxford University Press.

Morgan, M. S., \& Rutherford, M. (1998). American economics: The character of the transformation. History of Political Economy, $30,1-26$.

North, D., \& Thomas, R. (1973). The rise of the western world: A new economic history. New York: Cambridge University Press.

Pirgan Matur, E. (2007). Kurumsal iktisat (Institutional economics). Ankara: İmge Kitabevi.

Portelli, H. (1982). Gramsci e le bloc historique (Kenan Somer). Ankara: Ankara Savaş Yayınları.

Pratten, S. (2004). Mathematical formalism in economics: Consequences and alternatives. Institute of Economic Affairs, 24, $37-42$.

Ransom, R. S., \& Walton, G. (1982). Explorations in the new economic history: Essays in honor of Douglass C. North. New York: Academic Press.

Yaylagül, L. (2006). Kitle iletişim kuramlari egemen ve eleştirel yaklaşımlar (The theories of mass communication, dominant and critical approaches). Ankara: Dipnot Yayınları. 